\title{
What Role Can Propinquity Play in the Development of New National Allegiances? Immigrant Latinos Establishing Ties to the United States through Out-Group Contact
}

\author{
Christopher Olds \\ Department of Political Science, College of Arts \& Sciences, University of Kentucky, Lexington, USA \\ Email: chris@chrisolds.com
}

Received January $24^{\text {th }}, 2012$; revised February $28^{\text {th }}, 2012$; accepted March $10^{\text {th }}, 2012$

\begin{abstract}
Contact theory has primarily been applied to the study of interactions between Blacks and Whites, with particular emphasis on changes in the attitudes of Whites towards Blacks. How individual contact with an out-group can influence not just attitudes, but also actual behavior, has not been thoroughly explored. Through an analysis of the 2006 Latino National Survey, using a measure that contrasts the intensity of individual social interaction with various ethnic and racial groups, the study shows that a high intensity of friendly social contact with African-Americans increases the likelihood Latino immigrants will establish a closer link to the social and political structures of the United States. Latino immigrants are potentially experiencing movement towards deprovincialization through high levels of friendly social interaction with African-Americans. The development of friendly personal interactions with an out-group stigmatized in the mother country can help Latino immigrants develop an optimistic view of life in the host country.
\end{abstract}

Keywords: Contact Theory; Deprovincialization; Out-Group Contact; Inter-Group Relations; Propinquity; Latino Immigrants; Latino Politics

\section{Introduction}

Although the United States is rich with diversity, most of the research on inter-group relations in America has heretofore looked primarily at interactions between Whites and Blacks (e.g. Sigelman \& Welch, 1993; Bledsoe et al., 1995; Stein, Post, \& Rinden, 1998). This previous research is focused on whether Whites display more positive attitudes toward Blacks following increased interaction with individuals who are African-American. The belief is that Whites ultimately become as comfortable interacting with members of a different racial group (classified as the out-group) as they would with members of their own racial group (classified as the in-group).

Unfortunately, not enough attention has been paid to the consequences of interactions between different sets of racial and ethnic groups in the United States (although see Goebes \& Shore, 1978; Carlson, Wilson, \& Hargrave, 2003; Kao \& Joyner, 2004; Benitto, 2010). It is unclear if the effects seen following contact between Whites and Blacks are observable following contact between Latinos and Blacks, Blacks and Asians, Whites and Latinos, etc. In addition, while we have some sense of how in-group/out-group interactions have the potential to transform attitudes, it is not as clear how in-group/out-group interactions can influence social and political behavior.

An attempt to address this gap in the existing literature is performed in this project through an analysis of the 2006 Latino National Survey. The responses to this survey offer the capacity to determine if a high intensity of friendly social interaction with African-Americans, instead of a high intensity of friendly social interaction with other groups, increases the likelihood of Latino immigrants establishing an allegiance to the host country, the United States. This is an important result, given the rapid influx of Latino immigrants in recent years (de la Garza, 2004). As will be explained, friendly contact with African-Americans should assist Latino immigrant adaptation to the American sociopolitical system.

While propinquity has been thought to produce positive consequences in that negative attitudes between groups subside, this study shows another potential benefit-Latino immigrants forging ties with the United States system, both socially and politically. As recent research outside of the context of the United States (Costoiu, 2008; Hamberger, 2009) has discussed immigrant perceptions of belonging in the host country, it is worthwhile to examine whether Latino immigrants develop closer ties to the United States following increased friendly contact with an out-group traditionally stigmatized in the mother country.

\section{Past Research on the Contact Hypothesis and Inter-Group Relations}

\section{The Contact Hypothesis}

The contact hypothesis proposes that frequent social engagement with out-groups modifies how individuals view out-groups. Negative attitudes toward out-groups ultimately subside upon increased interaction (Allport, 1954; Hood \& Morris, 1998; McClain et al., 2006). Groups that do have negative expectations of each other usually try to avoid contact with each other (Rothbert \& John, 1993; Shelton, Richeson, \& Bergsieker, 2009). Oliver and Wong (2003) find that individuals who live with out-groups display more positive attitudes regarding out-groups.

Increased interaction between two groups who usually possess ill feelings towards each other will lead hostile attitudes to wane (Hood \& Morris, 1998). Friendships with members of an outgroup can limit anxiety stemming from pessimistic expectations of future interactions with other members of that out-group (Page- 
Gould, Mendoza-Denton, \& Tropp, 2008; Shelton et al., 2010). The reason is that first-hand social interaction with members of the out-group helps to change preconceived notions of the group (Allport, 1954).

A body of research states that in order for the effects of propinquity to occur, inter-group contact has to meet a certain set of conditions (Jackman \& Crane, 1986; Amir, 1969; Brewer \& Kramer, 1985; Powers \& Ellison, 1994; Moody, 2001). Scholars believe that the contact must not have a competitive context attached to it, the contact has to be prolonged and not isolated, and the contact must afford equal status to all parties involved.

There has yet to be a resolution in the scholarship to the question of whether all conditions need to be met before inter-group contact will exhibit any of the hypothesized effects. Nonetheless, in the process of analyzing the question, many studies have found an association between increased racial contact and more positive attitudes regarding out-groups (Sigelman \& Welch, 1993; Bledsoe et al., 1995; Stein, Post, \& Rinden, 1998; Welch \& Sigelman, 2000; Pettigrew \& Tropp, 2000; Welch et al., 2001; McClain et al., 2006). The point is that little social interaction with groups from different backgrounds preserves ignorance about these groups. This can breed hostile predispositions towards those from other backgrounds (Jackman \& Crane, 1986). It could be though that in-group social norms about the value of inter-group contact is as much a factor in predicting attitudes about out-groups as actual positive interactions with out-group members (JasinskajaLahti, Mähönen, \& Liebkind, 2010).

There are several studies that have moved beyond a review of the role of propinquity on changing out-group attitudes, instead examining the influence of inter-group relations on policy attitudes. In particular, the focus is on how Whites respond to interaction with Blacks through their preferences on issues often linked to the African-American population (Kinder \& Sears, 1981; Bobo \& Kluegel, 1993; Kinder \& Sanders, 1996; Gilens, 1999; Federico \& Sidanius, 2002). A detailed study from Taylor and Mateyka (2011) of one hundred localities shows that in those localities with a large Black population, White respondents hold less progressive racial attitudes. Such a finding suggests that greater residential proximity to Blacks, increasing the probability of contact, actually heightens Anglo hostility towards Blacks.

Some effort has been made to see Anglo responses to contact with other groups. For instance, Hood and Morris (1998) find increased Anglo support for immigration with an increase in the population size of documented migrants. A higher potential for interaction with documented migrants can help to shape views on immigration.

\section{Concerns about the Contact Hypothesis Literature}

Nonetheless, the areas of inquiry in which contact theory has been applied are relatively limited. There is a paucity of work discussing how out-group contact changes not just attitudes, but behavior as well. For instance, it is unknown whether increased contact with out-groups helps people learn about others in such a way to increase their willingness to engage in social and political collective activities. The building of common associations with out-groups can spur an increase in the practice of collective action. This is not a far-fetched assumption to make. With contact, individuals should become more knowledgeable of others, and should become less likely to avoid members of outgroups. The information collected through interaction helps individuals find common ties with each other (Crosby, Bromley, \& Saxe, 1980; Dovidio, Gaertner, \& Kawakami, 2003).
In addition to a dire need to examine the role of out-group contact on behavior, testing the applicability of contact theory with other sets of groups is essential. Doing this will address the generalizability concern regarding contact theory. There have been prior attempts looking at inter-group relations Latinos exhibit with Whites and Blacks in school settings (Goebes \& Shore, 1978; Carlson, Wilson, \& Hargrave, 2003). In addition, longitudinal research on adolescent friendships show lower levels of shared activity with Black friends amongst White, Asian, and Latino youths, suggesting lower friendship intimacy with Black friends (Kao \& Joyner, 2004). Initial attempts have been made to evaluate specific religious groups, as seen in efforts to interview Arab women in America and Britain to determine the impact of intergroup contact on views about multiculturalism (Benitto, 2010).

Researchers that have looked at contact theory from the perspective of Blacks as the in-group find that the attitudes of Blacks are tied more to feelings about the in-group, rather than feelings about any out-group (Herring, Jankowski, \& Brown, 1999; Sniderman \& Piazza, 1993). This could mean contact theory's proposed effects only work with a specific in-group/ out-group pairing.

McClain et al. (2006) attempted to see if this was the case by looking at the response of Latino immigrants to increased social contact with Blacks. The study found that Latino immigrants who had higher levels of social contact with Blacks were less likely to hold negative stereotypes of Blacks. Contact with Blacks contributed to Latino immigrant expression of more positive attitudes toward Blacks. This current project picks up where the McClain et al. (2006) project left off. The intention of this project is to evaluate whether social contact not only influences immigrant attitudes about out-groups, but can also influence immigrant social and political behavior.

\section{Can Contact Hypothesis Determine Whether Deprovincialization of Latino Immigrants Occurs?}

The social and political behavior of interest in this project involves immigrant establishment of closer ties to the host country, the United States. The proposal is that social contact while in the host country with an out-group historically stigmatized in the mother country can result in more positive attitudes about living in the host country. Such attitudes help to lower nationalistic pride (Dovidio, Gaertner, \& Kawakami, 2003). More contact with members of a specific out-group can lead individuals to appreciate new cultures and reconsider their own cultural standards. Individuals ultimately come to embrace the values of other cultures and distance themselves from the in-group culture (Verkuyten, Thijs, \& Bekhuis, 2010). Pettigrew (1997) classifies this process as deprovincialization. The proposal is that "in-group norms, customs and lifestyles turn out not to be the only ways to manage the social world... those with out-group friends gain distance from their own group and form a less provincial perspective on other groups in general" (1997: p. 174).

In the case of this project, an increase in Latino immigrant social engagement with African-Americans should lead many Latino immigrants to shed away much of the preconceived negative stereotypes or even hostilities held about Blacks that are unfortunately engrained in citizens of many Latin American states (Dulitzky, 2001). Although there are Latin American states that historically have not, or currently do not, recognize formal racial groups and/or collect information about racial demographics (Safa, 1998; de la Torre, 1999), the reality is that 
skin color is a pervasive influence on the socio-cultural framework of most Latin American countries. There is a substantial amount of scholarship that suggests employment opportunities and income distributions are tied to a social hierarchy rooted in color, as well as the limited political mobility or opportunities available for non-White citizens (e.g. Hasenbalg, 1994; Lovell \& Wood, 1998; Whitten \& Torres, 1998; Sansone, 1998; Fry, 2000; de la Fuente, 2001).

For these reasons, the development of friendships with African-Americans might be more conducive than friendships with Americans of an Anglo-Saxon origin to the cultivation of the view that the culture of the host country is worth embracing. The reason is that being light-skinned is something that is an aesthetic ideal and indicator of social status to many Latin American citizens (Uhlmann et al., 2002). Increased social interactions with White Americans will not change the view that there is a hierarchy in society rooted in color, whereas more social interactions with Black Americans could help Latino immigrants move away from the perspective that skin color is an indicator of status in the host country. The prediction of the project is that undergoing the process of deprovincialization will lead Latino immigrants to adopt the view that there is not as pervasive a racial hierarchy in the host country as exists in the mother country. This could help Latino immigrants develop the perspective that in the host country, there is more equality of opportunity in advancement, regardless of background. Such an outlook can drive Latino immigrants to become interested in establishing closer ties to the United States, given that they can personally benefit from this perceived equality in opportunity.

In short, an increase in friendly social interaction with Blacks in the host country should lower Latino immigrant reluctance in establishing formal ties to the host country. Frequent friendly social interactions in a new country with an out-group traditionally stigmatized in their country of origin should lead Latino immigrants to reconsider their preconceived views about this group. This reappraisal will bring about a consideration of whether the socio-cultural values of the host country embrace a wider variety of backgrounds than the mother country. If individuals come to hold this view through a process of deprovincialization, there is the possibility Latino immigrants will shift away from attachments to their mother country, and will find it increasingly worthwhile to become socially and politically linked to the United States.

The development of meaningful out-group friendships could then have the possibility of bringing about other outcomes in addition to positive out-group relations (Antonio, 2001). Out-group friendships with a group stigmatized in the mother country could make immigrant Latinos attempt to preserve those friendships and adhere to the socio-cultural values of the host country by staying in the United States.

Establishing ties with the American system can be exhibited in a variety of ways. One, Latino immigrants can become naturalized citizens of the United States. An immigrant's decision to apply for citizenship is a major decision; it is one way in which an immigrant can demonstrate they are interested in becoming integrated politically in the new state (Grebler, 1966; Blumentahl, 1971). Garcia (1981) elaborates, suggesting that an immigrant essentially transfers their psychological affiliation from their mother country to the host country they migrated to.

Second, immigrants can engage in the communities of their host country, by participating in social, civic, or political groups. This is perhaps the most obvious way in which Latino immi- grants can participate in the system, as other avenues of participation like voting or making political donations are a bit more cost intensive for immigrants (Sanchez, 2006).

Lastly, an immigrant can state a preference for staying to live in the United States. Many Latino immigrants have torn national allegiances between their mother country and their host country, with many returning to their mother country after a period of time in the United States (Oboler, 2006; Jones-Correa, 1998). If Latinos immigrants do not wish to return to their mother country to live, then they have likely established ties to their host country. The proposal here is that contact with outgroups is one means in which to establish those ties.

\section{Potential Alternative Explanations for Latino Immigrant Engagement with the American System}

The contact hypothesis is not the only available explanation for engagement with the American system. In-group ties have been shown to influence how individuals think about their orientation towards the system. Huddy (2003) states group identification entails a subjective sense of membership. Possessing a social identity means an individual believes they belong to a social group, and this knowledge has some level of significance tied to it (Tajfel, 1981; Berman \& Wittig, 2004). Some believe the possession of a group identity helps to frame the way in which individuals view the political world. For instance, Conover (1984) and Tate (1993) find that group identifiers devote more attention than others to issues linked to their group's interests.

This group identification is thought of as one element of group consciousness. Group consciousness means an individual identifies with a group, is aware of the group's position in society, and is committed to acting with the group to improve the groups' interests (Jackman \& Jackman, 1973; Gurin, Miller, \& Gurin, 1980; Miller et al., 1981). A substantial amount of research has already looked into whether group consciousness can help drive political action (e.g. Olsen, 1970; Miller et al., 1981; Sanchez, 2006). Efforts to produce change comes largely from individuals that feel they belong to a disadvantaged group, and see working within the group as the best means in which to improve their relative position in life (Kelly \& Breinlinger, 1996; Kawakami \& Dion, 1993; Garcia, 2003; Berman \& Wittig, 2004).

Studies looking into influence of group consciousness in fostering political action believe there are three necessary factors. First, there has to be a sense of group identification. Second, individuals should believe the group is fraternally deprived. This means that the group one belongs to has a consistently low level of status in society, especially in comparison to other groups. Third, the system of government is blamed for exclusion from the socio-political system. This is reflected in part by feelings that there is a disparity in terms of what the in-group enjoys compared to out-groups, and that members of the ingroup lack a voice in what the government does. The presence of these three factors produces political cohesion that could drive political action (Huddy, 2003: pp. 529-531). It could be that Latino immigrants who exhibit all three of these views are more likely to make an effort to advance the cause of their group. The first step to go about this is to establish ties to the American system (naturalize, participate in group activities, and abstain from returning to the mother country).

The last potential explanation is the standard model to ex- 
plain participation in the United States, the socioeconomic model. An increase in personal socioeconomic levels should increase the likelihood of social and political activity. The belief is that individuals with certain qualities, like enjoying a higher level of formal education or coming from a higher level income bracket, will be more likely to engage with the system (Verba \& Nie, 1972; Verba, Nie, \& Kim, 1978). Latino immigrants could be more willing to develop ties to the American system if they enjoy higher socioeconomic status.

\section{Research Hypotheses}

Given all these potential explanations, there are three hypotheses evaluated to help determine which factors will predict whether Latino immigrants will establish ties to the host country of the United States.

Hypothesis \#1-An increase in social contact with Blacks will help Latino immigrants develop ties to the American political system.

a) Latino immigrants with higher levels of social interaction with Blacks are more likely to become naturalized citizens of the United States.

b) Latino immigrants with higher levels of social interaction with Blacks are more likely to participate in the activities of a community group in the United States.

c) Latino immigrants with higher levels of social interaction with Blacks are less likely to have plans to return to their mother country.

Hypothesis \#2-An increase in group consciousness will help Latino immigrants develop ties to the American political system.

a) Latino immigrants who increasingly identify with their in-group, have a sense their group is fraternally deprived, and believe the system of government is exclusionary, are more likely to become naturalized citizens of the United States.

b) Latino immigrants who increasingly identify with their in-group, have a sense their group is fraternally deprived, and believe the system of government is exclusionary, are more likely to participate in the activities of a community group in the United States.

c) Latino immigrants who increasingly identify with their in-group, have a sense their group is fraternally deprived, and believe the system of government is exclusionary, are less likely to have plans to return to their mother country.

Hypothesis \#3 - An increase in personal socioeconomic status will help Latino immigrants develop ties to the American political system.

a) Latino immigrants with higher socioeconomic status (education and income) are more likely to become naturalized citizens of the United States.

b) Latino immigrants with higher socioeconomic status (education and income) are more likely to participate in the activeties of a community group in the United States.

c) Latino immigrants with higher socioeconomic status (education and income) are less likely to have plans to return to their mother country.

\section{Data and Model Specification}

To examine the impact of out-group contact on Latino immigrant behavior given alternative explanations, interview responses from the Latino National Survey are used. The survey, conducted between late 2005 to midway through 2006, consists of responses from native and non-native born Latinos living in 471 counties of 17 American states (Georgia, Virginia, North Carolina, Illinois, Arkansas, Arizona, Texas, New Mexico, California, Florida, New York, Iowa, New Jersey, Maryland, Colorado, Nevada, and Washington). The survey has the advantage of having responses from areas with a history of having sizable Latino populations residing there, and areas where there are emerging Latino populations (Fraga et al., 2006).

Although over 8600 interviews were completed, the analysis here looks only at the preferences of non-native/non-Black identifying Latino immigrants. The project evaluates the answers of 4258 respondents. Since the study in part is interested in explaining the decision to naturalize, respondents of immigrants from the US Commonwealth of Puerto Rico are not included.

There are three dependent variables analyzed. The first looks into whether the respondent has become a naturalized citizen (1 $=$ yes, $0=$ no). The second measures whether the respondent has participated in the activities of a social, cultural, civic, or political group $(1=$ yes, $0=$ no). Lastly, whether the respondent plans to go back to their mother country to live permanently is studied $(1=$ yes, $0=$ no $)$.

A random intercept hierarchical linear model is used because it allows one to construct the most accurate representation of the available information about respondents. Individuals in the population reside in counties of specific states. This means there is a data hierarchy wherein separate units are grouped at different levels - simply put, multiple levels of data exist (Luke, 2004). In this case, Latino immigrant respondents can be thought of as the level-one unit, counties are the level-two units, and states are the level-three unit. In multilevel modeling, we can make inferences about our dependent variables using a function made up of variables at multiple levels, while simultaneously modeling possible systematic differences between levels (such as between counties and between states).

Using a random intercept model in this case is not superfluous usage of sophisticated quantitative methodology. In using this model, we are taking into full consideration the possibility that there is a different intercept within each group (Gelman \& Hill, 2007). In random intercept models people in different groups start in different places. Due to the random intercept, we say some groups have on average higher responses on the dependent variable, while other groups have lower responses. In other words, the multilevel model takes into consideration that certain groups will tend to have a particular response for the dependent variable, while others groups will tend to have another response (Snijders \& Bosker, 1999: p. 41). A legitimate proposal to make is that Latinos from certain counties and states will tend to have more of an allegiance to the American system than others, as there are numerous communities with socially and politically established Latino populations (Stamps \& Bohan, 2006). This aspect is something that needs to be considered when mapping out the empirical analysis, and the random intercept model is one means in which to do this.

Since all dependent variables studied are binary dependent variables, a transformation using the logit link function is used: $\eta_{i j k}=\operatorname{logit}\left(\mathrm{Y}_{\mathrm{ijk}}\right)$. Here, the letter "ip" indexes individual respondents. The letter " $\mathrm{j}$ " is the index for the county level grouping, and the letter " $k$ " is the index for the state level grouping. We are looking at the dependent variable $Y_{i j k}$ for respondent " $i$ " in county " $\mathrm{j}$ " in state " $\mathrm{k}$ ". The full structure of the model can be represented using notation employed by Steenbergen and Jones 
(2002).

In level-one, the model is represented below:

$\eta_{\mathrm{ijk}}=\alpha_{0 \mathrm{jk}}+\alpha_{1 \mathrm{jk}}$ Social Contact with Blacks $\mathrm{ijk}_{\mathrm{j}}+\alpha_{2 \mathrm{jk}}$ Strength of Latino Identity $\mathrm{ijk}_{\mathrm{jk}}+\alpha_{3 \mathrm{jk}}$ Believe Government is Exclusionary ${ }_{\mathrm{ijk}}$ $+\alpha_{4 \mathrm{jk}}$ Fraternal Deprivation ${ }_{\mathrm{ijk}}+\alpha_{5 \mathrm{jk}}$ Household Income $_{\mathrm{ijk}}+\alpha_{6 \mathrm{jk}}$ Length of Time in the United States $\mathrm{ijk}+\alpha_{7 \mathrm{jk}}$ Education $_{\mathrm{ijk}}$.

It is important to see that there is no term identified here for the level-one error variance. As Luke (2004: p. 55) states, with binary dependent variables, the variance will be determined by the mean and is not estimated as a separate term. In addition, the variables Fraternal Deprivation, Household Income, and Length of Time in the United States are grand-mean centered and all other level-one predictors are not centered. Grand-mean centering means you center a predictor on the grand-mean of that particular variable. The intercept in this case can be interpreted as an adjusted mean.

In terms of level-one predictors, Social Contact with Blacks is the key variable of interest, with a higher score representing a higher degree of personal interaction with Blacks. Respondents were asked to describe the racial composition of their friends. Survey participants that state their friends were mostly Black receive a score in this analysis representing the highest degree of social contact with Blacks (the coding of this variable and all others derived from the survey instrument are presented in the Appendix). Given the coding of the variable, the measure also accounts for whether respondents interact primarily with nonBlack out-group members (Whites, Asians, etc.) and/or members of the in-group (other Latinos/Hispanics). The benefit of using this survey item as the representation of social contact is that it implicitly follows the conditions some scholars see as necessary for propinquity to have its proposed effect. When one interacts with a friend, there should not be a competitive context attached to interactions. The interaction is also consistent over time, instead of infrequent. In addition, friends should certainly consider each other of equal status (Jackman \& Crane, 1986).

As stated previously, there are other possible explanations as to the orientation of Latino immigrants toward the United States. It might be that interaction with out-groups is less of an influence on ties to the United States than feelings about the ingroup. Strength of Latino Identity is based on the response to the question of how strongly the respondent thought of themselves as a Hispanic or Latino. Higher scores mean the respondent thinks more strongly of themselves as Latino. The variable Believe Government is Exclusionary is an additive-index score based on the response to several questions evaluating government in the United States. A higher score means the respondent thinks the government has little beneficial impact on their life. The variable Fraternal Deprivation measures the perception of whether Latinos have the opportunity to advance in the United States through hard work. A higher value on this variable means the respondent is more pessimistic about the prospects for Latinos.

An alternative to consider is that personal demographic factors drive how much Latino immigrants will develop social and political ties with the U.S. system. Latinos who make more, have spent more time in the United States, or have more formal education, could be more likely to see utility in actively participating with American social and political structures. Household Income is the natural log of the total household income. Length of Time in the United States measures the number of years in which the respondent has lived in the U.S. This is calculated by subtracting the year in which the interview occurred from the time in which the respondent said they arrived to live in the U.S. The last level-one predictor, Education, describes the highest level of formal education the respondent completed at the time of the interview.

Going forward, $\alpha_{0 j k}$ is the intercept for level-two unit $j$ within level-three unit k. For this intercept, we construct the level two-model as follows:

$$
\alpha_{0 \mathrm{jk}}=\beta_{00 \mathrm{k}}+\beta_{01 \mathrm{k}} \text { Population African-American }{ }_{\mathrm{jk}}+\delta_{0 \mathrm{jk}}
$$

where Population African-American represents the percent of the county's population that is African-American. This variable is considered in an attempt to control for the concern that the ability to engage socially with an out-group is influenced by the size of the African-American population in the area. One's friendships are not going to be totally based on personal choice, as patterns of interaction will be determined by the social proximity of individuals (Festinger, Schacter, \& Back, 1950; Vander Zanden, 1984). The information for this variable comes from the U.S. Census Bureau's 2000 county demographic profile. This indicator is also grand-mean centered. As should be clear, $\alpha_{0 \mathrm{jk}}$ in part is a function of a level-two predictor. All other level-one coefficients are fixed. $\beta_{00 \mathrm{k}}$ is the average intercept in level-three unit k. For this intercept, we need to introduce the level-three model with state level predictors:

$\beta_{00 \mathrm{k}}=\gamma_{000}+\gamma_{001}$ African-American Per Capita Income Advantage $_{\mathrm{k}}+\gamma_{002}$ African-American Elected Officials Advantage $\mathrm{e}_{\mathrm{k}}$ $+\gamma_{003}$ Percent of Latinos Unemployed ${ }_{k}+\gamma_{004}$ Percent of Latinos Uninsured $_{\mathrm{k}}+v_{\text {ook }}$.

The effects of all the state level predictors are fixed. The intention of including these variables is to consider the possible impact of aggregate economic, political, and social performance of Latinos on individual behavior. African-American Per Capita Income Advantage measures how much greater the average aggregate income divided by total population is for Blacks relative to Latinos. The information for this variable is calculated from the U.S. Census Bureau's 2000 state demographic profile. African-American Elected Officials Advantage measures how many more African-American elected officials there are in the state compared to Latino elected officials. The number of elected officials for each minority group is measured by adding information collected about state legislatures and governorships in 2006 and 2007 by the Gender and Multicultural Leadership Project's National Database of Non-White Elected Officials.

If there is a sharp and clear disparity in the sociopolitical level Blacks have relative to Latinos within a state, Latino immigrants could be less willing to establish ties to the host country. Latino immigrants that perceive it to be difficult to reach a certain level of status in the state they reside in relative to others might see little benefit in becoming more closely linked to the United States.

Percent of Latinos Unemployed is collected from Wendel's (2002) state economic profiles. Percent of Latinos Uninsured comes from information collected between 2005 and 2006 by the Henry J. Kaiser Family Foundation. All state level predictors were grand-mean centered except for African-American Elected Officials Advantage. Latino immigrants who live in a state with a high unemployed or uninsured Latino population could perceive little benefit in making the effort to establish ties to the system.

Given this, we can rewrite the $\alpha_{0 \mathrm{jk}}$ intercept function by con- 
sidering aspects of the level-three model:

$\alpha_{0 \mathrm{jk}}=\gamma_{000}+\gamma_{001}$ African-American Per Capita Income Advantage $_{\mathrm{k}}+\gamma_{002}$ African-American Elected Officials Advantage $+\gamma_{003}$ Percent of Latinos Unemployed ${ }_{k}+\gamma_{004}$ Percent of Latinos Uninsured $_{\mathrm{k}}+\beta_{01 \mathrm{k}}$ Population African-American $_{\mathrm{jk}}+v_{\mathrm{ook}}+\delta_{0 \mathrm{jk}}$.

All three levels of the model can now be combined into a single equation. The ultimate model used to analyze the three dependent variables is presented as follows:

$\gamma_{000}+\gamma_{001}$ African-American Per Capita Income Advantage $\mathrm{k}_{\mathrm{k}}$ $+\gamma_{002}$ African-American Elected Officials Advantage $e_{k}+\gamma_{003}$ Percent of Latinos Unemployed Un $_{\mathrm{k}}+\gamma_{004}$ Percent of Latinos Uninsured $_{\mathrm{k}}+\gamma_{010}$ Population African-American $_{\mathrm{jk}}+\gamma_{100}$ Social Contact with Blacks $\mathrm{ijk}_{\mathrm{jk}}+\gamma_{200}$ Strength of Latino Identity $_{\mathrm{ijk}}+\gamma_{300}$ Believe Government is Exclusionary ${ }_{\mathrm{ijk}}+\gamma_{400}$ Fraternal Deprivation $_{\mathrm{ijk}}+\gamma_{500}$ Household Income $_{\mathrm{ijk}}+\gamma_{600}$ Length of Time in the United States $\mathrm{ijk}_{\mathrm{jk}}+\gamma_{700}$ Education $_{\mathrm{ijk}}+v_{\mathrm{ook}}+\delta_{0 \mathrm{jk}}$.

One thing that should be clear upon a full review of the model is that it does not factor in the possibility of a self-selection bias on the part of Latino immigrants in their contact with out-groups. Some work engaged with the contact hypothesis believes there is a strong possibility of a self-selection bias present (e.g. Sigelman \& Welch, 1993; Jackman \& Crane, 1986). The concern is that individuals who lack prejudice toward an out-group are more apt to interact with the out-group than individuals who are prejudiced.

Powers and Ellison (1994) helped to assuage these fears in their usage of endogenous switching regression models. The two found that models employing contact with out-groups as an exogenous variable to predict racial attitudes fail to exhibit the sample selection bias critics suggest exists. Oliver and Wong's (2003) study of the impact of living with out-groups on attitudes toward out-groups also found no evidence of a self-selection bias. Given that there is a history of research that shows no evidence of a self-selection bias present, and also an inability to construct a reasonable (given existing literature) representation of prejudice with the survey instrument, this issue is not addressed in the empirical analysis.

It should be noted that the models evaluated here do not include a country of origin variable. A reason for this is that this would introduce a fourth level of grouping into the model where a lack of accurate information exists about the relative size of the non-White population within that country. Indeed, as mentioned above, some Latin American countries either previously or currently refuse to collect racial demographics for information gathering purposes like census data (Safa, 1998; de la Torre, 1999). In addition, the Latino National Survey instrument does not ask questions regarding an individual respondent's level of interaction with out-groups in their mother country. Models unreported in this paper were performed that treated country of origin as a level-one variable; the inclusion of this variable as a level-one indicator did not change any of the findings that are reported in the results section. A table of descriptive statistics for the variables used in this project is provided immediately below (Table 1).

\section{Results}

The results of the three multilevel models across the board confirm the main proposal of the project. Increased social contact with Blacks increases the likelihood Latino immigrants will establish ties to the American system. The initial results analyze the determinants of Latino immigrant naturalization. The results are reported in Table 2.

The coefficient of Social Contact with Blacks is significant and positive. Gelman and Hill (2007: p. 82) offer a relatively easy way in which to interpret logistic regression coefficients like this one. All coefficients other than the intercept term can be divided by four to obtain an upper bound of the predictive difference that corresponds to a unit difference in that predictor. The reason for this is that the upper bound is a legitimate approximation near the midpoint of the logistic curve. In the case of the Social Contact with Blacks coefficient, each additional unit in the level of social contact with Blacks corresponds to an approximate $5 \%$ positive difference in the probability of the immigrant having become a naturalized citizen of the United States. Latino immigrants who develop friendly relationships with Blacks are more likely to make the effort to obtain most of the rights enjoyed by natural-born citizens.

Table 1.

Descriptive statistics.

\begin{tabular}{lcccc}
\hline \multicolumn{1}{c}{ Variable Name } & Mean & Std. Dev & Min & Max \\
\hline Social Contact with Blacks & 1.289 & 0.545 & 0 & 4 \\
Strength of Latino Identity & 2.540 & 0.734 & 0 & 3 \\
Believe Government is Exclusionary & 0.866 & 3.973 & -8 & 8 \\
Fraternal Deprivation & 1.230 & 0.542 & 1 & 4 \\
Natural Log Household Income & 9.070 & 0.732 & 6.908 & 11.156 \\
Length of Time in the United States & 17.540 & 12.115 & 0 & 79 \\
Education & 2.683 & 1.500 & 0.1 & 6 \\
Percent Population African-American in County & 13.665 & 13.107 & -2613 & 66.1 \\
African-American Per Capita Income Advantage & 2859.626 & -1182 & 6455 \\
African-American Elected Officials Advantage & -96.853 & 484.618 & 3.8 & 451 \\
Percent of Latinos Unemployed & 6.194 & 1.389 & 23 & 8.1 \\
Percent of Latinos Uninsured & 35.841 & 7.872 & 0 & 53 \\
Dependent Variable 1-Naturalized Citizen & 0.331 & 0.471 & 0 & 1 \\
Dependent Variable 2-Civic Engagement & 0.152 & 0.359 & 0 & 1 \\
Dependent Variable 3-Return to Mother Country & 0.280 & 0.449 & & \\
\hline
\end{tabular}


Table 2.

Determinants of Latino immigrant naturalization.

\begin{tabular}{lc}
\hline \multicolumn{1}{c}{ Parameter } & Multilevel Logit Estimate \\
\hline Intercept & $-2.31^{* * *}(0.243)$ \\
Individual Level Predictors & \\
Social Contact with Blacks & $0.192^{*}(0.0935)$ \\
Strength of Latino Identity & $0.106(0.0684)$ \\
Believe Government is Exclusionary & $-0.011(0.0128)$ \\
Fraternal Deprivation & $0.178^{*}(0.0858)$ \\
Natural Log Household Income & $0.511^{* * *}(0.0797)$ \\
Length of Time in the United States & $0.11^{* * *}(0.00533)$ \\
Education & $0.332^{* * *}(0.0358)$
\end{tabular}

\section{County Level Predictor}

Percent Population African-American in County

$0.003(0.00581)$

\section{State Level Predictors}

African-American Per Capita Income Advantage

African-American Elected Officials Advantage

Percent of Latinos Unemployed

$-0.00004(0.00004)$

$-0.0001(0.000189)$

$-0.084(0.0956)$

Percent of Latinos Uninsured

$-0.018(0.0119)$

Variance Components

County Level

$0.295(0.543)$

State Level

$0.0106(0.103)$

Deviance ( -2 x Log Likelihood)

150564

Number of Observations Individual Level $\quad 4258$

Number of Counties $\quad 471$

Number of States

17

Std. errors are placed in parentheses Significance Codes ${ }^{* * *}=0.001,{ }^{* *}=0.01,{ }^{*}=$ 0.05 .

There is relatively little support for the hypothesis suggesting group consciousness boosts efforts to engage in the system. Only the Fraternal Deprivation variable is significant in the predicted direction - those with increased feelings that the ingroup lacks the opportunity to advance in the U.S. are more likely to strive towards citizenship.

The hypothesis related to the importance of personal socioeconomic status in determining efforts to engage in the system cannot be ignored in this analysis. Both indicators, Income and Education, were each significant in the predicted direction. For instance, each additional unit in the level of formal education corresponds to about an $8 \%$ positive difference in the probability of an immigrant being naturalized. In addition, the personal demographic factor of Length of Time in the United States was also significant. For the Length of Time in the United States variable, each additional unit in the amount of time spent in the U.S. corresponds to an approximate $3 \%$ positive difference in the probability of the immigrant having become a naturalized citizen of the United States.

While the personal demographic and socioeconomic indicators appear to be a factor in the decision to naturalize, none of the county or state level predictors were significant in the model. It should also be noted that the estimated probability of having become a naturalized citizen with all predictors at a relevant value (with Social Contact with Blacks, Strength of Latino Identity, Believe Government is Exclusionary, Education, and African-American Elected Officials Advantage at zero, and all other predictors at their average value) is about $10 \%$ when looking at the inverse logit of the intercept term.
The results for the determinants of Latino immigrant civic engagement are fairly similar to those seen in the analysis on naturalization. The results of the second analysis are presented in Table 3. In terms of the intercept, we should predict the probability of civic engagement to be about $4 \%$ when all predictors are at a legitimate value of interest, as discussed above.

Again, the coefficient for Social Contact with Blacks is significant in the predicted positive direction. An additional unit in the level of social contact with Blacks corresponds to about a $5 \%$ positive difference in the probability of a Latino immigrant participating in a civic activity in the United States. Latino immigrants who engage with African-American citizens are increasingly likely to participate in the activities of a civic group in the United States.

Much like the previous analysis, there is not much empirical support for the proposal that group consciousness boosts participation in the American system. The coefficient for Believe Government is Exclusionary is significant in a direction opposite to predictions shaped from theories of group consciousness. The hypothesis is that if government fails to perceivably offer beneficial outcomes the in-group can enjoy, the likelihood of civic engagement would increase, not decrease. Instead of having a mobilizing effect as predicted by group consciousness research, Latino immigrants believing that government is exclusionary actually demobilizes. Latino immigrants that feel disenfranchised by government are less apt to develop ties to the system through civic engagement. In this instance, the view that government does a poor job of advancing the interests of the in-group lowers Latino immigrant civic engagement.

Table 3.

Determinants of Latino immigrant civic engagement.

\begin{tabular}{|c|c|}
\hline Parameter & Multilevel Logit Estimate \\
\hline Intercept & $-3.33^{* * *}(0.241)$ \\
\hline \multicolumn{2}{|l|}{ Individual Level Predictors } \\
\hline Social Contact with Blacks & $0.181^{*}(0.0889)$ \\
\hline Strength of Latino Identity & $0.016(0.0663)$ \\
\hline Believe Government is Exclusionary & $-0.0332^{* *}(0.0124)$ \\
\hline Fraternal Deprivation & $0.031(0.0844)$ \\
\hline Natural Log Household Income & $0.114(0.0751)$ \\
\hline Length of Time in the United States & $0.0271^{* * *}(0.00413)$ \\
\hline Education & $0.431^{* * *}(0.0342)$ \\
\hline \multicolumn{2}{|l|}{ County Level Predictor } \\
\hline Percent Population African-American in County & $-0.0041(0.00598)$ \\
\hline \multicolumn{2}{|l|}{ State Level Predictors } \\
\hline African-American Per Capita Income Advantage & $0.00003(0.00004)$ \\
\hline African-American Elected Officials Advantage & $0.0002(0.00019)$ \\
\hline Percent of Latinos Unemployed & $0.003(0.0911)$ \\
\hline Percent of Latinos Uninsured & $-0.005(0.0119)$ \\
\hline \multicolumn{2}{|l|}{ Variance Components } \\
\hline County Level & $0.295(0.543)$ \\
\hline State Level & $0.0106(0.103)$ \\
\hline Deviance ( -2 x Log Likelihood) & 148873 \\
\hline Number of Observations Individual Level & 4258 \\
\hline Number of Counties & 471 \\
\hline Number of States & 17 \\
\hline
\end{tabular}


Personal demographic and socioeconomic indicators, as was the case in decisions to naturalize, are indeed relevant in determining the likelihood of civic engagement. Increases in Length of Time in the United States and Education increase the likelyhood of participating in a civic group activity in the United States.

For the last analysis, there is the evaluation of Latino immigrant plans to return to their respective mother country. The presentation of the results is seen in Table 4. The proposal derived from the contact hypothesis is that increased social contact with African-Americans will lower the likelihood of wanting to return to one's mother country. This would reflect an increased willingness to develop ties with the United States. The hypothesis is confirmed once again, with each additional unit in the level of Social Contact with Blacks corresponding to an approximate $5 \%$ negative difference in the probability of an immigrant expressing plans to return to their respective mother country.

Yet again, there is little support offered for the group consciousness hypothesis, as none of the indicators are significant in the predicted direction. It appears Social Contact with Blacks plays more of a consistent factor in explaining whether Latino immigrants establish ties to the United States than specific views regarding the in-group. Personal demographic and socioeconomic variables are still relevant, as increases in Income and Length of Time in the United States each lower the likelihood of wanting to return to one's mother country. Latino immigrants at a certain demographic level in the United States are less willing to return to their country of origin.

Table 4.

Determinants of Latino immigrant preference to return to mother country.

\begin{tabular}{|c|c|}
\hline Parameter & Multilevel Logit Estimate \\
\hline Intercept & $-0.655^{* *}(0.218)$ \\
\hline \multicolumn{2}{|l|}{ Individual Level Predictors } \\
\hline Social Contact with Blacks & $-0.203^{*}(0.0893)$ \\
\hline Strength of Latino Identity & $-0.036(0.0604)$ \\
\hline Believe Government is Exclusionary & $0.017(0.0115)$ \\
\hline Fraternal Deprivation & $-0.066(0.0848)$ \\
\hline Natural Log Household Income & $-0.201^{* *}(0.0658)$ \\
\hline Length of Time in the United States & $-0.0535^{* * *}(0.00514)$ \\
\hline Education & $-0.016(0.0326)$ \\
\hline \multicolumn{2}{|l|}{ County Level Predictor } \\
\hline Percent Population African-American in County & $0.009(0.00553)$ \\
\hline \multicolumn{2}{|l|}{ State Level Predictors } \\
\hline African-American Per Capita Income Advantage & $0.00005(0.00004)$ \\
\hline African-American Elected Officials Advantage & $0.0006^{* *}(0.0002)$ \\
\hline Percent of Latinos Unemployed & $0.069(0.0939)$ \\
\hline Percent of Latinos Uninsured & $0.008(0.0109)$ \\
\hline \multicolumn{2}{|l|}{ Variance Components } \\
\hline County Level & $0.295(0.543)$ \\
\hline State Level & $0.0106(0.103)$ \\
\hline Deviance (-2 x Log Likelihood) & 144282 \\
\hline Number of Observations Individual Level & 4258 \\
\hline Number of Counties & 471 \\
\hline Number of States & 17 \\
\hline
\end{tabular}

Std. errors are placed in parentheses. Significance Codes ${ }^{* * *}=0.001,{ }^{* *}=0.01,{ }^{*}=$ 0.05 .
One result that stands out compared to the prior analyses is that a state level indicator, African-American Elected Officials Advantage, is both positive and significant. This could mean that an increase in the political advantage African-Americans appear to hold at the aggregate level could detract some Latino immigrants from staying in the United States.

In sum, the most consistent result seen in these analyses pertain to the possible link between social contact with Blacks and an increased willingness to establish ties to the United States. This gives some credence to the suggestion that through out-group contact, Latino immigrants can go through a process of deprovincialization. Latino immigrants perceive a different sociocultural framework exists in the United States relative to the mother country that they can potentially benefit from. This makes Latino immigrants less reluctant to establish formal ties with the host country.

\section{Discussion}

This study makes two contributions to the contact theory literature. First, the proposed positive effects of out-group contact are not merely confined to a potential drop in hostile attitudes toward other groups. Out-group contact can lead individuals to establish more of a link to the social and political system they live in. Out-group contact then does have the ability to influence behavior not explicitly tied to a racial context. This could mean the impact of propinquity is much wider than originally anticipated. Second, the study shows that proposed positive outcomes of out-group contact do not hold only in a White in-group/Black out-group setup. Latino immigrants responded in a positive way to high social contact with African-Americans. This means contact theory has the potential to be applicable to other combinations of groups in the United States. The implication of these findings will be worth exploring in multiple contexts, such as with immigrants to nations other than the United States, or with immigrants from alternative racial/ethnic backgrounds.

Future work should continue to explore whether inter-group contact has an impact on behavior with different sets of in-groups and out-groups. In the United States context regarding relations between Latinos and Blacks, extended study should see whether contact influences Latino immigrant behavior for more complex forms of participation, such as voting registration and participation.

Said analyses should then be compared with native-born Latino behavior following increased contact with Blacks to see if there is a difference in the response to out-group contact. And while it was not possible with the current survey instrument, the response of African-Americans to social interactions with Latinos is necessary to see if there is some equivalency in the positive impact of out-group contact on social behavior. Attempts should also be made to see if past experiences Latino immigrants have had with out-groups or exposure to certain sociocultural values in the mother country help to shape the role of out-group contact in the host country through the usage of a more expansive survey instrument.

Although contact theory has been around for decades, there are many untapped research questions tied to the hypotheses that should be explored. This analysis hopefully serves as an inspiration for further study.

\section{REFERENCES}

Allport, G. W. (1954). The nature of prejudice. Cambridge: Addison- 
Wesley.

Amir, Y. (1969). Contact hypothesis in ethnic relations. Psychological Bulletin, 71, 319-342. doi:10.1037/h0027352

Antonio, A. L. (2001). The role of interracial interaction in the development of leadership skills and cultural knowledge and understanding. Research in Higher Education, 42, 593-617. doi:10.1023/A:1011054427581

Benitto, M. (2010). Gender and intergroup contact: The case of Arab woman. Journal of Identity and Migration Studies, 4, 20-34.

Berman, S. L., \& Wittig, M. A. (2004). An intergroup theories approach to direct political action among African Americans. Group Processes and Inter-Group Relations, 7, 19-34. doi:10.1177/1368430204039971

Bledsoe, T., Welch, S., Sigelman, L., \& Combs, M. (1995). Residential contact and racial solidarity among African Americans. American Journal of Political Science, 39, 434-458. doi:10.2307/2111620

Blumenthal, S. D. (1971). The private organizations in the naturalization and citizenship process. International Migration Review, 5, 448462. doi:10.2307/3002146

Bobo, L., \& Kluegel, J. R. (1993). Opposition to race-targeting: Selfinterest, stratification ideology, or racial attitudes. American Sociological Review, 58, 443-464. doi:10.2307/2096070

Brewer, M. B., \& Kramer, R. M. (1985). The psychology of intergroup attitudes and behavior. Annual Review of Psychology, 36, 219-243. doi:10.1146/annurev.ps.36.020185.001251

Carlson, C. I., Wilson, K. D., \& Hargrave, J. K. (2003). The effect of school racial composition on Hispanic intergroup relations. Journal of Social and Personal Relationships, 20, 203-220. doi: $10.1177 / 02654075030202005$

Conover, P. J. (1984). The influence of group identifications on political perception and evaluation. Journal of Politics, 46, 760-785. doi: $10.2307 / 2130855$

Costoiu, A. (2008). Modes of minorities' integration: Explaining historical, economic, and political factors. Journal of Identity and Migration Studies, 2, 2-17.

Crosby, F., Bromley, S., \& Saxe, L. (1980). Recent unobtrusive studies of black and white discrimination and prejudice: A literature review. Psychological Bulletin, 87, 546-563. doi:10.1037/0033-2909.87.3.546

de la Fuente, A. (2001). A nation for all: Race, inequality, and politics in twentieth century Cuba. Chapel Hill: University of North Carolina Press.

de la Garza, R. O. (2004). Latino politics. Annual Review of Political Science, 7, 91-123. doi:10.1146/annurev.polisci.7.012003.104759

de la Torre, C. (1999). Everyday forms of racism in contemporary Ecuador: The experiences of middle-class Indians. Ethnic and Racial Studies, 22, 92-112. doi:10.1080/014198799329602

Dovidio, J. F., Gaertner, S. L., \& Kawakami, K. (2003). Intergroup contact: The past, present, and the future. Group Processes and Intergroup Relations, 6, 5-21. doi:10.1177/1368430203006001009

Dulitzky, A.E. (2001). A region in denial: Racial discrimination and racism in Latin America. Beyond Law, 8, 85-107.

Federico, C. M., \& Sidanius, J. (2002). Racism, ideology, and affirmative action revisited: The antecedents and consequences of 'principled objections' to affirmative action. Journal of Social and Personality Psychology, 82, 488-502. doi:10.1037/0022-3514.82.4.488

Festinger, L., Schacter, S., \& Back, K. (1950). Social pressures in informal groups: A study of human factors in housing. New York: Harper and Brothers.

Fraga, L. R., Garcia, J. A., Hero, R., Jones-Correa, M., Martinez-Ebers, V., \& Segura, G. M. (2006). Latino national survey: Executive summary. Washington, DC: Woodrow Wilson Center Presentation.

Fraga, L. R., Garcia, J. A., Hero, R., Jones-Correa, M., Martinez-Ebers, V., \& Segura, G.M. (2007). Latino national survey. URL. http://depts.washington.edu/uwiser/LNS.shtml

Fry, P. (2000). Politics, nationality, and the meanings of "race" in Brazil. Daedalus, 129, 83-118.

Garcia, J. A. (1981). Political integration of Mexican immigrants: Explorations into the naturalization process. International Migration Review, 15, 608-625. doi: $10.2307 / 2545515$

Garcia, J. A. (2003). Latino politics in America: Community, culture, and interests. Lanham, Maryland: Rowman and Littlefield Publishing Groups.

Gelman, A. \& Hill, J. (2007). Data analysis using regression and multilevel/hierarchical models. New York: Cambridge University Press.

Gilens, M. (1999). Why Americans hate welfare. Chicago: University of Chicago Press.

Goebes, D. D., \& Shore, M. F. (1978). Some effects of bicultural and monocultural school environments on personality development. American Journal of Orthopsychiatry, 48, 397-407.

Grebler, L. (1966). The naturalization of Mexican immigrants in the United States. International Migration Review, 1, 17-31. doi: $10.2307 / 3002232$

Gurin, P., Miller, A. H., \& Gurin, G. (1980). Stratum identification and consciousness. Social Psychological Quarterly, 43, 30-47. doi: $10.2307 / 3033746$

Hamberger, A. (2009). Immigrant integration: Acculturation and social integration. Journal of Identity and Migration Studies, 3, 2-21.

Hasenbalg, C. (1994). Perspectives on race and class in Brazil. Estudios Sociológicos, 12, 75-99.

Herring, M., Jankowski, T. B., \& Brown, R. E. (1999). Pro-Black doesn't mean anti-White: The structure of African-American group identity. Journal of Politics, 61, 363-386. doi:10.2307/2647508

Hood III, M. W., \& Morris, I .L. (1998). Give us your tired, your poor, but make sure they have a green card: The effects of documented and undocumented migrant context on Anglo opinion toward immigration. Political Behavior, 20, 1-15. doi:10.1023/A:1024839032001

Huddy, L. (2003). Group identity and political cohesion. In D. O. Sears, L. Huddy, \& R. Jervis (Eds.), Oxford handbook of political psychology (pp. 511-558). New York: Oxford University Press.

Jackman, M. R., \& Crane, M. (1986). "Some of my best friends are Black": Interracial friendship and Whites racial attitudes. Public Opinion Quarterly, 50, 459-486. doi:10.1086/268998

Jackman, M. R., \& Jackman, R. W. (1973). An interpretation of the relation between objective and subjective social status. American Sociological Review, 38, 569-582. doi:10.2307/2094408

Jasinskaja-Lahti, I., Mähönen, T. A., \& Liebkind, K. (2010). Ingroup norms, intergroup contact and intergroup anxiety as predictors of the outgroup attitudes of majority and minority youth. International Journal of Intercultural Relations, Online Access IJIR-750.

Jones-Correa, M. (1998). Between two nations: The political predicaments of Latinos in New York City. Ithaca, New York: Cornell University Press.

Kaiser Family Foundation. (2007). Kaiser state health facts database. URL. http://www.statehealthfacts.org/

Kao, G., \& Joyner, K. (2004). Do race and ethnicity matter among friends? Activities among interracial, interethnic, and intraethnic adolescent friends. The Sociological Quarterly, 45, 557-573. doi:10.1111/j.1533-8525.2004.tb02303.x

Kawakami, K., \& Dion, K. L. (1993). The impact of salient self-identities on relative deprivation and action intentions. European Journal of Social Psychology, 23, 524-541. doi:10.1002/ejsp.2420230509

Kelly, C., \& Breinlinger, S. (1996). The social psychology of collective action: Identity, injustice, and gender. New York: Taylor and Francis.

Kinder, D. R., \& Sanders, L. M. (1996). Divided by color: Racial politics and democratic ideals. Chicago: University of Chicago Press.

Kinder, D. R., \& Sears, D. O. (1981). Prejudice and politics: Symbolic racism versus racial threats to the good life. Journal of Personality and Social Psychology, 40, 414-431. doi:10.1037/0022-3514.40.3.414

Lovell, P. A. \& Wood, C. H. (1998). Skin color, racial identity, and life changes in Brazil. Latin American Perspectives, 25, 90-109. doi:10.1177/0094582X9802500305

Luke, D. (2004). Multilevel modeling. Thousand Oaks: Sage Publications.

McClain, P. D., Carter, N. B., DeFrancesco Soto, V. M., Lyle, M. L., Grynaviski, J. D., Nunnally, S. C., Scotto, T. J., Kendrick, J. A., Lackey, G. F., \& Cotton, K. D. (2006). Racial distancing in a Southern city: Latino immigrants' views of Black Americans. Journal of Politics, 68, 571-584.

Miller, A. H., Gurin, P., Gurin, G., \& Malanchuk, O. (1981). Group consciousness and political participation. American Journal of Po- 
litical Science, 25, 494-511. doi:10.2307/2110816

Moody, J. (2001). Race, school integration, and friendship segregation in America. American Journal of Sociology, 107, 679-716. doi: $10.1086 / 338954$

Oboler, S, (2006). Latinos and citizenship: The dilemma of belonging. New York: Palgrave Macmillan.

Oliver, J. E., \& Wong, J. (2003). Intergroup prejudice in multiethnic settings. American Journal of Political Science, 47, 567-582. doi: $10.2307 / 3186119$

Olsen, M. E. (1970). Social and political participation of Blacks. American Sociological Review, 35, 682-697. doi:10.2307/2093944

Page-Gould, E., Mendoza-Denton, R., \& Tropp, L. R. (2008). With a little help from my cross-group friend: Reducing anxiety in intergroup contexts through cross-group friendship. Journal of Personality and Social Psychology, 95, 1080-1094. doi:10.1037/0022-3514.95.5.1080

Pettigrew, T. F. (1997). Generalized intergroup contact effects on prejudice. Personality and Social Psychology Bulletin, 23, 173-185. doi:10.1177/0146167297232006

Pettigrew, T., \& Tropp, L. (2000). Does intergroup contact reduce prejudice? Recent meta-analytic findings. In S. Oskamp (Ed.) Reducing prejudice and discrimination (pp. 93-114). New Jersey: Lawrence Earlbaum Associates, Inc.

Powers, D. A., \& Ellison, C. G. (1994). Interracial contact and black racial attitudes: The contact hypothesis and selectivity bias. Social Forces, 74, 205-226. doi:10.2307/2580629

Rothbert, M., \& John, O. P. (1993). Intergroup relations and stereotype change: A social cognitive analysis and some longitudinal findings. In P. M. Sniderman, P. E. Tetlock, \& E. G. Carmines (Eds.) Prejudice, politics, and the American dilemma (pp. 32-59). Stanford, CA: Stanford University Press.

Safa, H. I. (1998). Introduction to race and national identity in the Americas. Latin American Perspectives, 25, 3-20. doi:10.1177/0094582X9802500301

Sanchez, G. R. (2006). The role of group consciousness in political participation among Latinos in the United States. American Politics Research, 34, 427-450. doi:10.1177/1532673X05284417

Sansone, L. (1998). Racism without ethnicity: Public policies and racial discrimination in comparative perspective. Dados, 41, 751-783.

Shelton, J. N., Richeson, J. A., \& Bergsieker, H. B. (2009). Interracial friendship development and attributional biases. Journal of Social and Personal Relationships, 26, 179-193. doi: $10.1177 / 0265407509106707$

Shelton, J. N., Trail, T. E., West, T. V., \& Bergsieker, H. B. (2010). From strangers to friends: The interpersonal process model of intimacy in developing interracial friendships. Journal of Social and Personal Relationships, 27, 71-90. doi:10.1177/0265407509346422

Sierra, C. M., Hardy-Fanta, C., Lien, P., \& Pinderhughes, D. M. (2007). National database of non-White elected officials. The gender and multicultural leadership project. URL. http://www.gmcl.org/database.htm

Sigelman, L., \& Welch, S. (1993). The contact hypothesis revisited: Interracial contact and positive racial attitudes. Social Forces, 71, 781795. doi: $10.2307 / 2579895$

Sniderman, P. M., \& Piazza, T. (1993). The Scar of Race. Cambridge, MA: Harvard University Press.

Snijders, T. A. B., \& Bosker, R. J. (1999). Multilevel analysis: An introduction to basic and advanced multilevel modeling. Thousand Oaks: Sage Publications.

Stamps, K., \& Bohon, S. A. (2006). Educational attainment in new and established Latino metropolitan destinations. Social Science Quarterly, 87, 1225-1240. doi:10.1111/j.1540-6237.2006.00425.x

Steenbergen, M. R., \& Jones, B. S. (2002). Modeling multilevel data structures. American Journal of Political Science, 46, 218-237. doi: $10.2307 / 3088424$

Stein, R. M., Post, S. S., \& Rinden, A. L. (1998). Reconciling context and contact effects on racial attitudes. Political Research Quarterly, 53, 285-303. doi: $10.1177 / 106591290005300204$

Tajfel, H. (1981). Human groups and social categories. Cambridge: Cambridge University Press.

Tate, K. (1993). From protest to politics: The new black voters in American elections. New York: Russell Sage.

Taylor, M. C., \& Mateyka, P. M. (2011). Community influences on white racial attitudes: What matters and why? The Sociological Quarterly, 52, 220-243. doi:10.1111/j.1533-8525.2011.01202.x

US Census Bureau. (2000). United States Census 2000 demographic profiles. URL. http://censtats.census.gov/pub/Profiles.shtml

Uhlman, E., Dasgupta, N., Elgueta, A., Greenwald, A. G., \& Swanson, J. (2002). Subgroup prejudice based on skin color among Hispanics in the United States and Latin America. Social Cognition, 20, 198225. doi:10.1521/soco.20.3.198.21104

Vander Zanden, J. W. (1984). Social psychology. New York: Random House.

Verba, S., \& Nie, N. H. (1972). Participation in America. New York: Harper and Row.

Verba, S., Nie, N. H., \& Kim, J. (1978). Participation and political equality: A seven nation comparison. Chicago, Illinois: University of Chicago Press.

Verkuyten, M., Thijs, J., \& Bekhuis, H. (2010). Intergroup contact and ingroup reappraisal: Examining the deprovincialization thesis. Social Psychology Quarterly, 73, 398-416.

Welch, S., \& Sigelman, L. (2000). Getting to know you? Latino-Anglo social contact. Social Science Quarterly, 81, 67-83.

Welch, S., Sigelman, L., Bledsoe, T., \& Combs, M. (2001). Race and place: Race relations in an American city. New York: Cambridge University Press.

Wendel, H. F. (2002). State profiles: The population and economy of each US state. Lanham, MD: Bernan Press.

Whitten, N. E., \& Torres, A., (Eds.) (1998). Blackness in Latin America and the Caribbean. Bloomington: Indiana University Press. 


\section{Appendix}

Presentation of Survey Items and Variable Codings

All variables that required manipulation from their original coding are presented below.

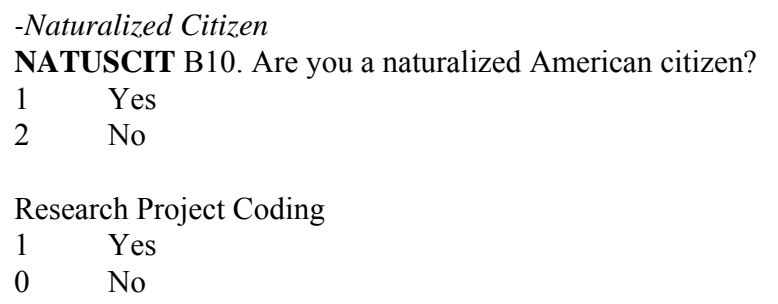

\section{-Civic Engagement}

COMPARP D1. Do you participate in the activities of one social, cultural, civic or political group, more than one such group, or do you not participate in the activities of any such groups?

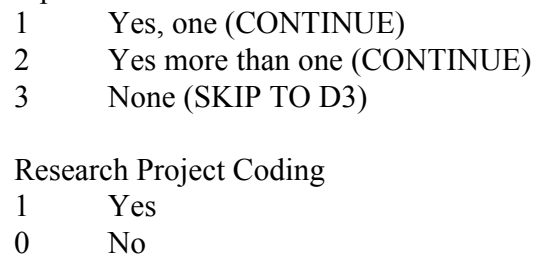

The reason this is collapsed into a dichotomous variable is that the original coding for the two "yes" responses are not informative enough-the "yes, more than one" response is much too vague about the actual number of activities participated in that it does not merit modeling as an ordered logit.

\section{-Return to Mother Country}

TRGOBACK M8. Do you have plans to go back to (mother country) to live permanently?

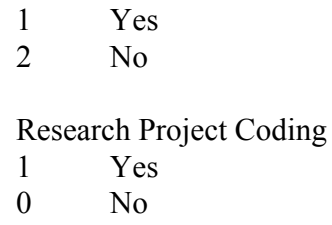

-Social Contact with Blacks

Original Survey Instrument Item

FRIENDS G6. How would you describe your friends? Are they (read response items)

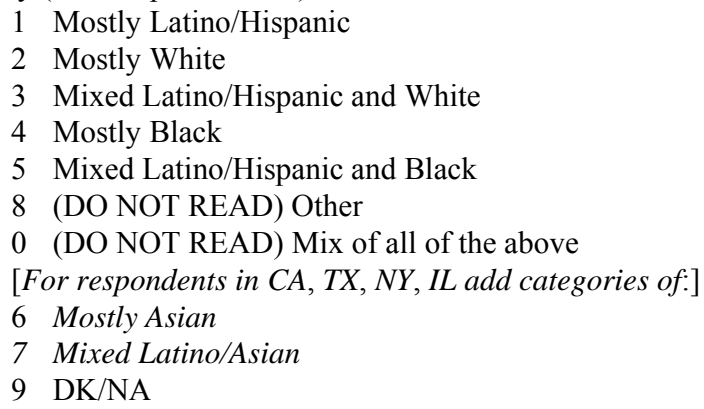

3 High Social Contact with Blacks (Mix of Latino and Black)

2 Moderate Social Contact with Blacks (Mix of all of the above)

1 Low Social Contact with Blacks (Mostly Latino, Mostly White, Mix Latino and White, Mostly Asian, Mix Latino and Asian, Other)

0 Very Low Social Contact (Cannot identify racial/ethnic makeup of friends)

\section{-Strength of Latino Identity}

Original Survey Instrument Item

LAIDENT L10. Finally, [In general,] how strongly or not do you think of yourself as Hispanic or Latino?
4 Very strongly
3 Somewhat strongly
2 Not very strongly
1 Not at all

Research Project Coding

3 Very strongly

2 Somewhat strongly

1 Not very strongly

0 Not at all

\section{-Believe Government is Exclusionary}

Original Survey Instrument Items

People have different ideas about the government in the United States. Please tell me how strongly you agree or disagree with each of these statements...

BIGINTST K3. A "Government is pretty much run by just a few big interests looking out for themselves, and not for the benefit of all the people."

4 Strongly agree

3 Somewhat agree

2 Somewhat disagree

1 Strongly disagree

9 Unsure

SAYSO K3. B "People like me don't have any say in what the government does." [Repeat only if necessary: Do you agree, neither agree nor disagree, or disagree with this statement?]
4 Strongly agree
3 Somewhat agree
2 Somewhat disagree
1 Strongly disagree
9 Unsure

COMPLIC C "Sometimes politics and government seem so complicated that a person like me can't really understand what's going on." [Repeat only if necessary: Do you agree, neither agree nor disagree, or disagree with this statement?]

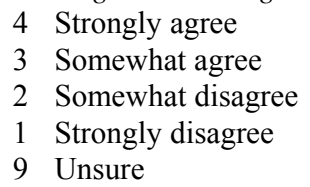

NOCONTACT D "People are better off avoiding contact with government" [Repeat only if necessary: Do you agree, 


\section{OLDS}

neither agree nor disagree, or disagree with this statement?]

4 Strongly agree

3 Somewhat agree

2 Somewhat disagree

1 Strongly disagree

9 Unsure

Research Project Coding

Each of the four items is recoded as follows

2 Strongly agree

1 Somewhat agree

0 Unsure

-1 Somewhat disagree

-2 Strongly disagree

After recoding, the scores from each response are summed into one total.

-Fraternal Deprivation

Original Survey Instrument Items

LATDISC N1.B Latinos can get ahead in the United States if they work hard?

4 Strongly Agree

3 Somewhat Agree

2 Somewhat Disagree

1 Strongly Disagree

Research Project Coding

1 Strongly Agree

2 Somewhat Agree

3 Somewhat Disagree

4 Strongly Disagree 